\title{
FABRICATION OF SUPERHYDROPHOBIC SURFACE WITH IMPROVED CORROSION INHIBITION ON AZ31B MAGNESIUM ALLOY SUBSTRATE
}

\author{
${ }^{1}$ SIMONOVA Maria, ${ }^{1}$ ABRASHOV Aleksey, ${ }^{1}$ GRIGORYAN Nelya, ${ }^{1}$ MEN'SHIKOV Vladimir, \\ ${ }^{1} \mathrm{KHAZANOV}$ Nikolay \\ ${ }^{1}$ MUCTR - D.Mendeleev University of Chemical Technology of Russia, Moscow, Russia \\ simonovamas11@rambler.ru
}

\section{https://doi.org/10.37904/metal.2021.4182}

\begin{abstract}
One of the recently demanded methods of protecting metal surfaces from aggressive environment is the formation on their surface of continuous films with water-repellent properties and the ability to self-cleaning, which give the material the property of super-hydrophobicity. The possibility of hydrophobization of the surface of the AZ31B magnesium alloy in a solution containing stearic acid, dimethyl sulfoxide and water has been investigated. It was found that the coating formed in this solution is characterized by a contact angle of $152-$ $162^{\circ}$.
\end{abstract}

Keywords: Protective hydrophobic coatings, hydrophobization, corrosion protection, magnesium alloy, surface treatment, stearic acid.

\section{INTRODUCTION}

In recent years, there has been an increase in the use of magnesium alloys as structural materials, due to the unique combination of properties: low specific gravity, high strength, ductility, damping ability and manufacturability. These materials are especially in demand in the aviation industry. Saving in weight of the structure when replacing aluminum is $20-30 \%[1,2]$.

The disadvantages of magnesium and its alloys are low corrosion resistance and scrub resistance. The low corrosion resistance of magnesium alloys is due to the high negative values of their standard potentials $(-2.37 \mathrm{~V})$. In real chloride environment, for example, in a $3 \%$ solution of sodium chloride, the potential of the AZ31B magnesium alloy is $1.38 \mathrm{~V}$, which is also much more negative than that of other structural metals and alloys.

One of the most effective methods of corrosion protection of magnesium alloys is the formation of continuous films with water-repellent properties on their surface to isolate the base material from the environment. Such films give the material the property of super-hydrophobicity.

In the literature, surfaces on which the contact angle exceeds $150^{\circ}$ are called super-hydrophobic. As a rule, obtaining super-hydrophobic surfaces involves two stages: the first stage consists in the formation of a surface with a micro-rough structure, and then in the modification of this surface with the use of compounds with low surface energy containing long alkyl and often perfluorinated chains [3-6]. To create roughness on the surface of metals, chemical etching in acidic or alkaline solutions is used [7-10]. Then the previously prepared surface is treated with hydrophobic reagents, for example, alkoxysilanes and their halogen derivatives.

In this work, a simple and at the same time environmentally friendly method of forming super-hydrophobic coatings on the surface of AZ31B magnesium alloy was studied. 


\section{EXPERIMENTAL MATERIALS}

For the application of superhydrophobic coatings, samples of magnesium alloy AZ31B of the size of $3 \times 4 \mathrm{~cm}$ were used.

Solutions were prepared of pure and pro analysis grades of chemicals and distilled water.

The protective ability of the coatings was determined by the express method using a solution of lead acetate $\mathrm{Pb}\left(\mathrm{CH}_{3} \mathrm{COO}\right)_{2} 10 \mathrm{~g} / \mathrm{l}$ [11]. The criterion for assessing the quality of the coating was the time until the color of the control area under the drop changed from gray to dark black for the magnesium base.

The surface roughness was studied with the help of profilograph-profilometer Mitutoyo SJ-310. Action of the device is based on the principle of feeling the irregularities of the investigated surface with a diamond needle. The resulting mechanical vibrations of the probe are converted (using an inductive primary converter) into voltage values proportional to these vibrations, which are amplified and converted by the electronic module. The measurement results are shown on the liquid crystal display and on the printer.

The contact angle $\left(\theta_{c}\right)$ of water during contact with the surface of the magnesium plates was measured on the "Goniometer LK-1». The photos of drops were taken with the camera "Levenhuk C310 NG", and then the wetting angle was calculated with the help of DropShape software.

To determine the corrosion resistance, the samples were placed in a $0.05 \mathrm{M} \mathrm{NaCl}$ solution and kept for 72 hours at room temperature (GOST 9.913-90) [12]. Inspection of the samples was carried out 3 times a day to establish the time before the appearance of the first spot of corrosion. Before evaluating corrosion tests, corrosion products were removed from the surface of the samples. After removal of corrosion products, the samples were washed in running water and then in distilled water, and dried in an oven at a temperature of $100 \pm 2^{\circ} \mathrm{C}$ for 3-5 min.

Current-voltage and impedance studies of the corrosion of magnesium samples with coatings were carried out using an IPC potentiostat with an FRA attachment and a three-electrode glass cell thermostated at $25^{\circ} \mathrm{C}$ in $3 \% \mathrm{NaCl}$. The counter electrode was a titanium plate, the surface area of which significantly exceeded the overall area of the working electrode. The potentials were measured relative to a saturated silver -chloride electrode and then recalculated to the scale of a standard hydrogen electrode. The potential sweep rate when obtaining voltammograms was $50 \mathrm{mV} / \mathrm{s}$. The impedance was measured in a potentiostatic mode at a stationary potential in the frequency range $0.1 \mathrm{~Hz}-20 \mathrm{kHz}$ at a potential oscillation amplitude of $10 \mathrm{mV}$.

To analyze the equivalent circuits and calculate the denominations of their elements, the DCS program (Dummy Cell Solver), created by V.E. Kasatkin (IPCE RAS), was used. This program allows you to calculate the theoretical frequency dependence of the impedance of the selected circuit and compare it with the experimentally obtained dependence. The optimization of the nominal values of the elements of the selected equivalent circuit is performed according to the criterion of minimizing the relative error between the experimental and simulated values of the impedance vectors for each measurement in the investigated range.

\section{EXPERIMENTAL}

The possibility of hydrophobization of the surface of AZ31B magnesium alloy in a solution containing stearic acid, dimethyl sulfoxide (DMSO) and water has been investigated.

\subsection{Determination of the hydrophobic coatings depositing process parameters}

Before coating, samples of AZ31B magnesium alloy with a size of $3 \times 4 \mathrm{~cm}$ were pretreated. First, the samples were degreased in a solution containing $40 \mathrm{~g} / \mathrm{l} \mathrm{NaOH}$ and $40 \mathrm{~g} / \mathrm{l} \mathrm{Na} 2 \mathrm{SiO}_{3}$ at room temperature for 3 minutes. Then the purified samples were etched in a solution containing 20-50 g/l HNO 3 at room temperature for 1 minute. After each stage, washing in distilled water was carried out. Then, magnesium samples were immersed 
in a hydrophobizing solution of stearic acid $(\mathrm{SA})$ at a $\mathrm{DMSO} / \mathrm{H}_{2} \mathrm{O}$ ratio $(7: 1)$ at room temperature [13]. It is believed that in the presence of a solvent (for example, DMSO), an organic fatty acid in an aqueous solution dissociates. This process is accompanied by an increase in the acidity of the solution, leading to the dissolution of the natural oxide film on the magnesium alloy and the subsequent formation of a conversion hydrophobic coating according to the scheme:

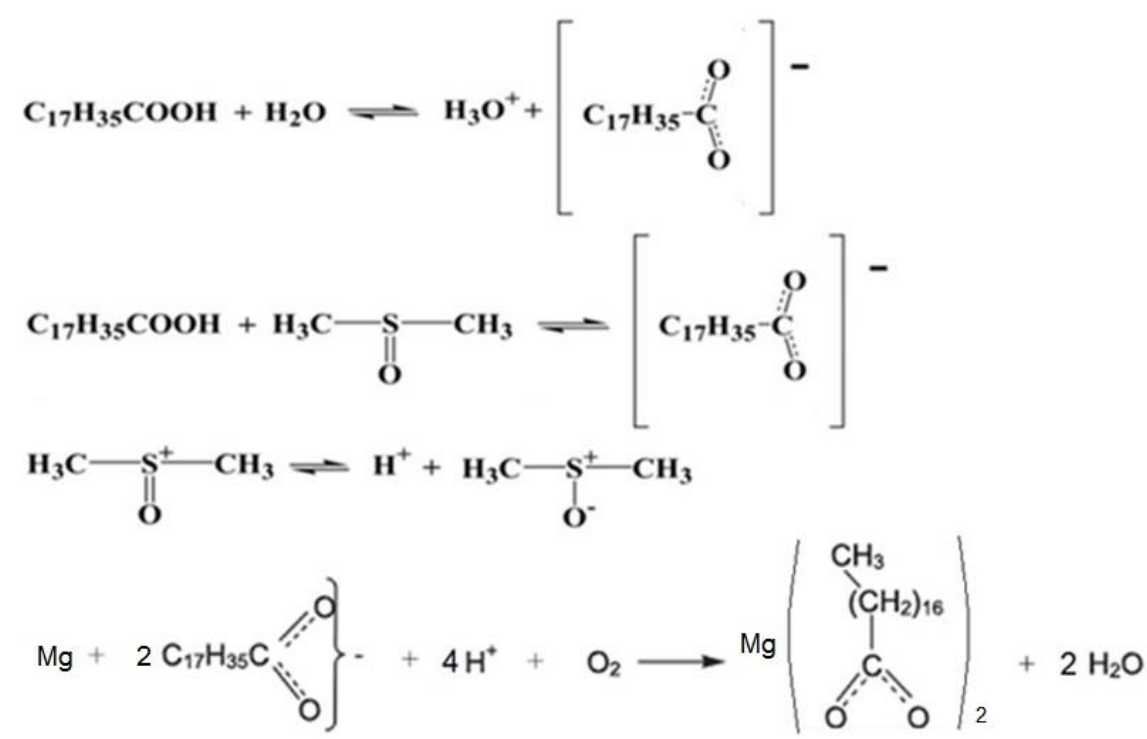

It has been established that in the concentration range 2.0-4.0 g/l of stearic acid in the solution, homogeneous continuous coatings with a protective ability (PA) of 130-200 s are formed on the surface of magnesium alloy. The contact angle $\left(\theta_{c}\right)$ is $141-155^{\circ}$. The coatings, as can be seen from the above scheme, consist of magnesium stearates and, as was established using a spectroscopic ellipsometer, their thickness is $270-300$ $\mathrm{nm}$.

As expected, the protective ability of coatings depends on the temperature of the working solution. Coatings with the highest protective ability of $241 \mathrm{~s}$ are formed at a temperature of $40-50^{\circ} \mathrm{C}$. At this process temperature, it is possible to obtain super-hydrophobic coatings on magnesium alloy $\left(\theta_{c}=162^{\circ}\right)$. Heating up to $60^{\circ} \mathrm{C}$ is allowed, the contact angle is still $>150^{\circ}$, however, under such conditions, the protective ability of the formed films decreases $(\mathrm{PA}=64 \mathrm{~s})$.

The influence of the treatment duration on the protective characteristics of coatings was investigated. It was found that coatings with the largest contact angle $\left(\theta_{c}=162^{\circ}\right)$ and the highest protective ability $(270-300 \mathrm{~s})$ are formed in 5-15 minutes of the process (Figure1).
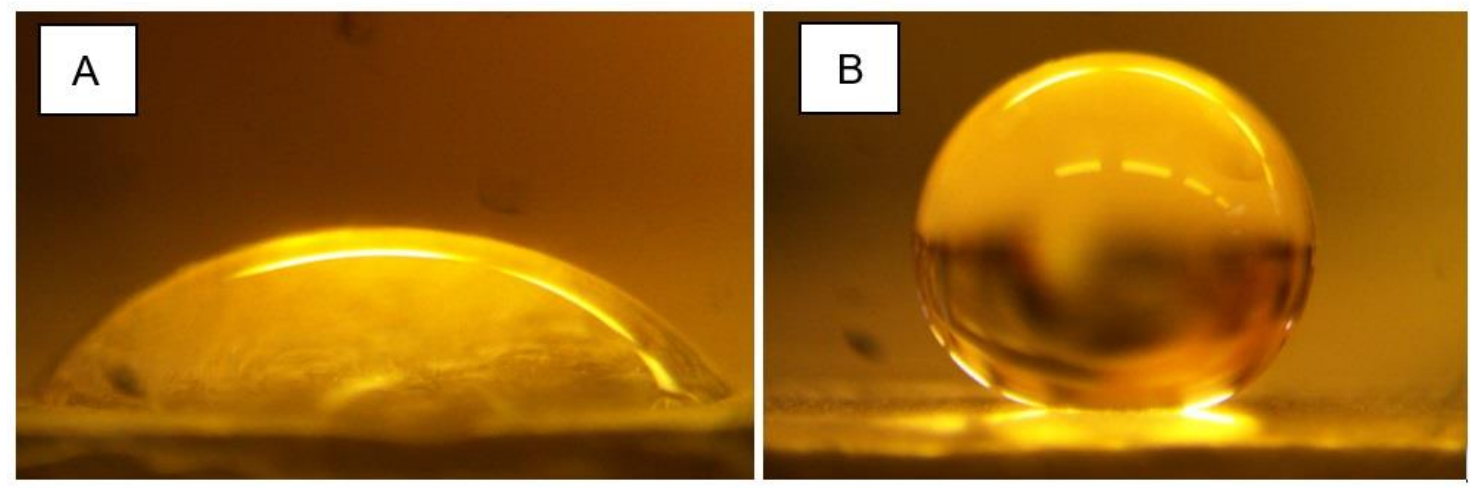

Figure 1 Photo of a water drop on the surface of a magnesium alloy (A - sample AZ31B without coating $\theta_{c}=66^{\circ}$; B - hydrophobized alloy AZ31B $\theta_{c}=162^{\circ}$ ) 
To obtain coatings with high hydrophobic properties, it is important to create an appropriate surface morphology, that is, surface with multimodal roughness. The influence of the preliminary stages of preparation of AZ31B magnesium alloy on the surface roughness (Table 1), protective ability and the contact angle of the coatings (Table 2) was studied. It has been established that the samples have the highest roughness after degreasing and subsequent etching in nitric acid. Also, with this surface preparation, the best characteristics of the coatings are observed (Table 2).

Table 1 Surface roughness of samples

\begin{tabular}{|c|c|c|c|c|c|}
\hline \multirow[b]{2}{*}{$\begin{array}{c}\text { Roughness } \\
\text { index, } \\
\mu \mathrm{m}\end{array}$} & \multicolumn{5}{|c|}{ Surface preparation } \\
\hline & $\begin{array}{l}\text { Without } \\
\text { surface } \\
\text { preparation }\end{array}$ & $\begin{array}{c}\text { Degreasing in } \\
\text { solution } \\
\mathrm{NaOH}+\mathrm{Na}_{2} \mathrm{SiO}_{3}\end{array}$ & $\begin{array}{l}\text { Etching in } \\
\text { solution } \\
\mathrm{HNO}_{3}\end{array}$ & $\begin{array}{c}\text { Degreasing } \\
\left(\mathrm{NaOH}+\mathrm{Na}_{2} \mathrm{SiO}_{3}\right)+ \\
\text { etching }\left(\mathrm{HNO}_{3}\right)\end{array}$ & $\begin{array}{c}\text { Degreasing } \\
\left(\mathrm{NaOH}_{+} \mathrm{Na}_{2} \mathrm{SiO}_{3}\right)+ \\
\text { etching }\left(\mathrm{HNO}_{3}\right)+ \\
\text { coating }\end{array}$ \\
\hline $\mathrm{Ra}$ & 0,769 & 0,886 & 1,071 & 1,203 & 0,762 \\
\hline $\mathrm{Rq}$ & 1,001 & 1,185 & 1,427 & 1,737 & 0,974 \\
\hline $\mathrm{Rz}$ & 5,392 & 6,219 & 8,171 & 8,226 & 4,977 \\
\hline $\mathrm{Rp}$ & 2,962 & 3,084 & 3,315 & 3,657 & 2,285 \\
\hline Rv & 2,430 & 3,135 & 4,856 & 5,170 & 2,691 \\
\hline
\end{tabular}

Table 2 Characteristics of the obtained coatings depending on the surface preparation

\begin{tabular}{|c|c|c|c|c|}
\hline $\begin{array}{c}\text { Surface } \\
\text { preparation }\end{array}$ & $\begin{array}{l}\text { Without surface } \\
\text { preparation }\end{array}$ & $\begin{array}{l}\text { Degreasing in solution } \\
\qquad \mathrm{NaOH}+\mathrm{Na}_{2} \mathrm{SiO}_{3}\end{array}$ & $\begin{array}{l}\text { Etching in solution } \\
\qquad \mathrm{HNO}_{3}\end{array}$ & $\begin{array}{c}\text { Degreasing } \\
\left(\mathrm{NaOH}+\mathrm{Na}_{2} \mathrm{SiO}_{3}\right)+ \\
\text { etching }\left(\mathrm{HNO}_{3}\right) \\
\end{array}$ \\
\hline Protective ability, s & 53 & 71 & 134 & 277 \\
\hline Contact angle, ${ }^{\circ}$ & 140,81 & 149,16 & 157,09 & 162,28 \\
\hline
\end{tabular}

\subsection{Tests of the coatings}

Corrosion tests in $0.05 \mathrm{M} \mathrm{NaCl}$ solution were carried out. Samples of magnesium alloy with a hydrophobic coating were immersed in the solution for $1 \mathrm{~h}, 4 \mathrm{~h}, 24 \mathrm{~h}, 30 \mathrm{~h}, 48 \mathrm{~h}$, and $72 \mathrm{~h}$, respectively, after which they were removed and dried. The results of measuring the contact angle of the obtained coating over time indicate a relatively high stability of the hydrophobic properties of the coating. Thus, the decrease in the contact angle after exposure of the coated samples in the solution after $30 \mathrm{~h}$ is insignificant, the coating still save its hydrophobic properties (the contact angle is $>90^{\circ}$ ), but after $48 \mathrm{~h} \theta_{\mathrm{c}}$ is only $71^{\circ}$, which indicates the loss of hydrophobic properties and degradation of the protective coating (Figure 2). Also, tests have shown that the first spot of corrosion of the base appear after 4 hours of exposure in an aggressive environment. After 30 hours of testing, the base corroded by $30 \%$, and after 48 hours by $80 \%$.

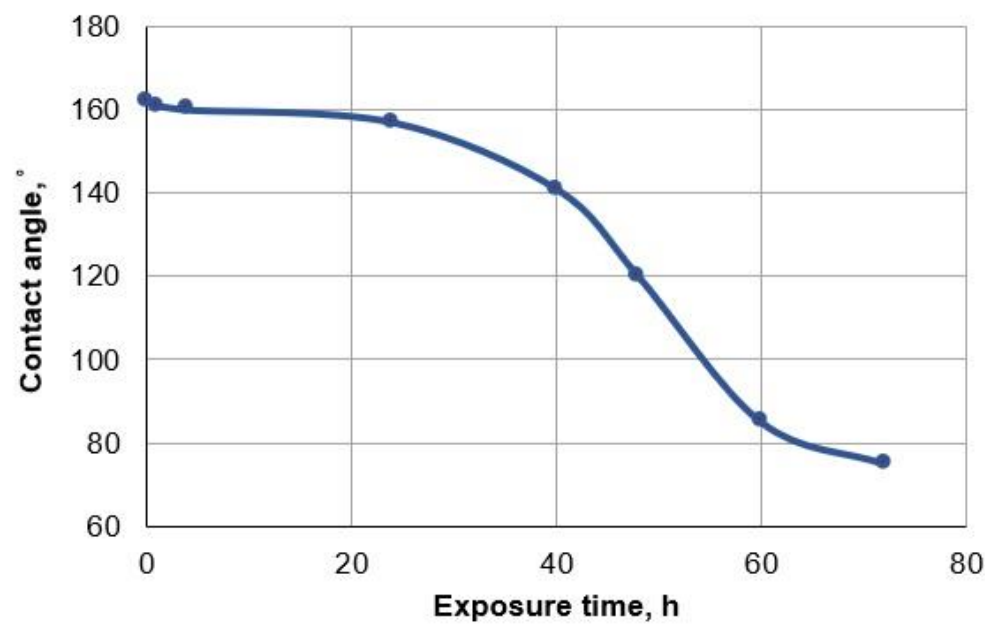

Figure 2 Dependence of the contact angle on the exposure time in $0.05 \mathrm{M} \mathrm{NaCl}$ solution 
In this work, impedance spectroscopy was also used to compare the protective characteristics of conversion coatings.

Protective coatings can be described by an equivalent circuit (Figure 3), consisting of active resistance (R0), which is the resistance of the electrolyte, the capacitance of the electric double layer (CPE1), which is the geometric capacity of the conversion film, and the active resistance (R1), which is the polarization resistance of the conversion coating, the pseudo-inductive resistance (R2), which is the polarization resistance to the corrosion process, and the pseudo-induction capacitance (CPE2), which is the capacitance of the metal/coating interface.

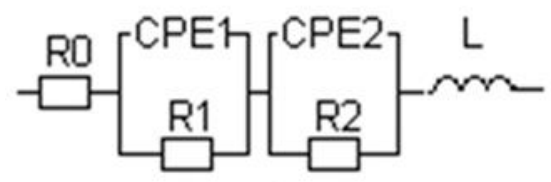

Figure 3 Equivalent circuit simulating the behavior of magnesium alloy with a protective coating in a $3 \%$ $\mathrm{NaCl}$ solution

Nyquist diagrams (hodographs) for magnesium alloy samples with various conversion coatings obtained in $3 \%$ $\mathrm{NaCl}$ solution are shown in (Figure 4).

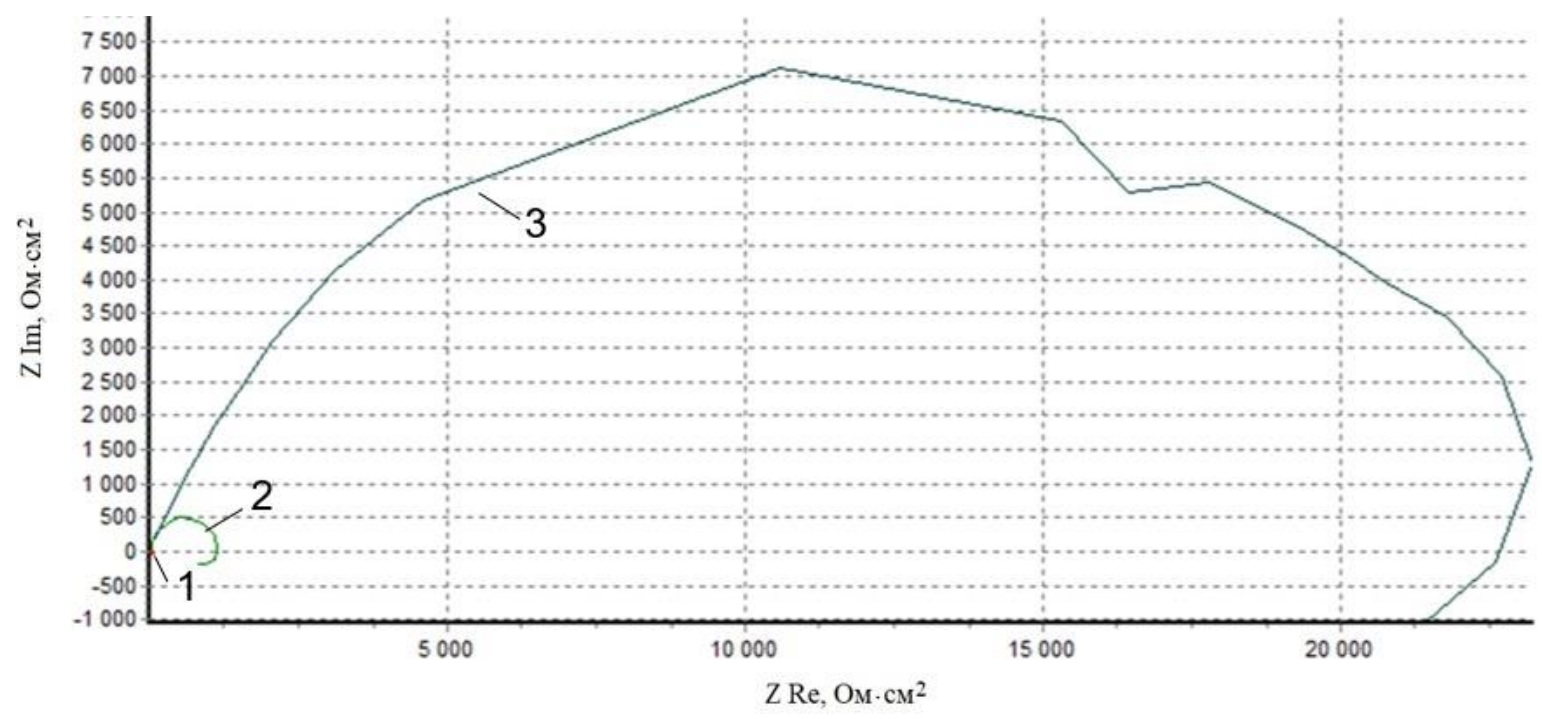

Figure 4 Nyquist diagrams for magnesium samples with protective coatings:

1 - Mg; 2 - $\mathrm{Cr}(\mathrm{VI}) ; 3$ - superhydrophobic coating.

It is known that hodographs show charge transfer resistance from solution to metal and vice versa, so the larger the hodograph loop, the more difficult this process is, and, therefore, the hodographs can be used to assess the barrier characteristics of the coatings. The given hodographs indicate that the greatest difficulties in charge transfer occur in the case of a super-hydrophobic coating.

It should be noted that the results of impedance spectroscopy are consistent with the above results of corrosion tests.

\section{CONCLUSION}

As a result, a solution for applying a super-hydrophobic coating on the AZ31B magnesium alloy, which surpasses chromate coatings in terms of corrosion resistance and protective ability was developed. Such coating can be an alternative to chromate coatings. 


\section{ACKNOWLEDGEMENTS}

\section{The work was supported by the Mendeleev University of Chemical Technology of Russia. Project Number X-2020-028}

\section{REFERENCES}

[1] CAO, F., SONG, G.-L., ATRENS, A. Corrosion and passivation of magnesium alloys. Corrosion Science. 2016, vol. 111, pp. 835-845.

[2] CASTANO, C. E., MADDELA, S., O'KEEFE, M. J., WANG, Y. M.A. Comparative Study on the Corrosion Resistance of Cerium-Based Conversion Coatings on AZ91D and AZ31B Magnesium Alloys. ECS Transactions. 2012, vol. 41, no.15, pp. 3-12.

[3] SHI, F., CHEN, X., WANG, L., NIU, J., et al. Roselike Microstructures Formed by Direct In Situ Hydrothermal Synthesis: From Superhydrophilicity to Superhydrophobicity. Chemistry of Materials. 2005, vol. 17, pp. 61776180.

[4] ZHAO, L., LIU, Q., GAO, R., WANG, J., et al. One-step method for the fabrication of superhydrophobic surface on magnesium alloy and its corrosion protection, antifouling performance. Corrosion Science. 2014, vol. 80, pp. 177.

[5] ABOHALKUMA, T., SHAWISH, F., TELEGDI, J. Phosphonic acid derivatives used in self assembled layers against metal corrosion. International journal of corrosion and scale inhibition. 2014, vol.3, pp. 151.

[6] HOQUE, E., DEROSE, J.A., HOFFMANN, P, MATHIEU, H. J., et al. Phosphonate self-assembled monolayers on aluminum surfaces. The journal of chemical physics. 2006, vol. 124, p. 174710.

[7] RAN, M., ZHENG, W., WANG, H. Fabrication of superhydrophobic surfaces for corrosion protection: a review. Materials Science and Technology. 2019, vol. 35, no. 3, pp. 1-14.

[8] YAO, W., WU, L., HUANG, G., JIANG, B., et al. Superhydrophobic coatings for corrosion protection of magnesium alloys. Journal of Materials Science \& Technology. 2020, vol. 52, pp. 100-118.

[9] SHE, Z., LI, Q., WANG, Z., LI, L., et al. Researching the fabrication of anticorrosion superhydrophobic surface on magnesium alloy and its mechanical stability and durability. Chemical Engineering Journal. 2013, vol. 228, pp. 415-424.

[10] JIN, Q., TIAN, G., LI, J., ZHAO, Y., et al. The study on corrosion resistance of superhydrophobic magnesium hydroxide coating on AZ31B magnesium alloy. Colloids and Surfaces A: Physicochemical and Engineering Aspects. 2019, vol. 577, pp. 8-16.

[11] ABRASHOV, A.A., GRIGORYAN, N.S., SIMONOVA, M.A., ASNIS, N.A. Adgezionnyye konversionnyye pokrytiya pod lakokrasochnyye pokrytiya na magniyevykh splavakh (Adhesive conversion lacquer coatings on magnesium alloys). Tsvetnyye metally. 2019, no. 10, pp. 66-71.

[12] GOST 9.913-90. Unified system of protection against corrosion and aging. Aluminum, magnesium and their alloys. Accelerated corrosion test methods.

[13] SPIRIDONOVA, A., ABRASHOV, A., GRIGORYAN, N., BESSONOVA, K., et al. Stearic acid modified aluminum alloy 5556. In: Conference Proceedings 28 th Anniversary International Conference on Metallurgy and Materials (METAL 2019). Brno: Tanger, 2020, pp. 1158-1162. 